\title{
絶対座標系の動作記述とキネマティクスに基づいた
}

\section{2 足ロボットの動歩行制御の実現}

\author{
学生員 真 島 勝 行 (長岡技術科学大学) \\ 学生員 宮 崎 敏 昌 (長岡找料学大学) \\ 正員大石潔 (長岡技術科学大学)
}

Dynamic Gait Control of Biped Robot Based on Kinematics and Motion Description in Cartesian Space Katsuyuki Majima, Toshimasa Miyazaki, Student-member and Kiyoshi Ohishi, Member (Nagaoka University of Technology)

This paper proposes a new dynamic gait control method of biped robot based on robust joint servo control. The method consists of two subjects. The first subject is the approximation of biped robot to the inverted pendulum for sagittal plane and lateral plane. The second subject is the constitution of dynamic gait control based on robust joint servo control and kinematics.

The motion description in Cartesian space is determined from the motion of the inverted pendulum for sagittal plane and lateral plane. Suitability of the biped motion reference is confirmed by distribution of ZMP(Zero Moment Point). Using the inverse kinematics of biped robot, the biped motion references in Cartesian space is transformed to the position references in joint space. In joint space, the robust position control system consists of two-degrees-of-freedom control system based on coprime factorization and disturbance observer. Since the robust joint servo control system compensates the inertia variation and disturbance torque on dynamic gait control, this control system is suitable for the dynamic gait control of biped robot. The validity of the proposed method is confirmed by the experimental results.

キーワード：2 足ロボット、動歩行制御、キネマティクス、ZMP、ロバスト位置制御

\section{1.はじめに}

2 足歩行ロボットの動歩行制午に関して、これまで基本 的に勳力学問題に基づく制御で行われてきた (1)(2)(3)(4)(5)。 動力学問題に基づく制御法では、非線形の複雑な逆動力学 計算を用いることで、ロボットの力や位置などをシンプル な線形制御としている。これは、制御量がトルクであるた め、所望の出力応答を達成するための各関節トルクを計算 する。この逆動力学計算は、その計算量と各パラメータの 精度などが実現上の問題となる。また、動力学問題に基づ くロボットの動作は、複雑な非線形方程式となる。そのた め、動步行を実現する非線形方程式の解を直接求めて行 手法は、ほとんど例がない。また、2 足步行ロボットの有効 な制御手法として、倒立振子近似による方法がよく用いら れる ${ }^{(5)(6)}$ 。この手法は、一質点系で 2 足ロボットを表現する ため、その片足支持期における運動特性を、比較的容易に 記述することができると同時に、片足支持期における安定 性についてもより簡単に考虑できる。しかしながら、この 方法も最終指令值がトルクとなる逆動力学計算を抱えてし まう制御方式が一般的である。
これに対して、動力学問題を用いずにロボットを制御す る方法として、各関節をロバスト加速度制御して、絶対座 標系での指令值を関節空間座標に座標变換して制御する力 法が提案されてきた(7)(8)(9)。このロバスト加速度制御に基 づく 2 足步行ロボットの動歩行制御は、実用的でシンブル な方法であるが、まだ 3 次元動歩行までには至っていない (10)。各関節をロバスト位置制御する方法で動歩行させる方 法として、近似した倒立振子の長さを擬似的に変化させる ことで歩行の加减速を行う手法が提案されている(11)。この 方法では、歩行の指令を関節空間において生成しているの で、実際の動步行指令としてはなじみにくい。これに対し て、絶対座標系で歩行指令を記述することは、設計者にとっ て簡便性を与えるとともに、種々の目的のための歩行動作 指令生成をより簡単にできる。

本論文では、絶对座標系における歩行のための動作記述 及びキネマティクス、そして各関節を動作させるロバスト 位䈯制御の3つを構成する。これらに基ついて、動力学問 題を用いずに 2 足ロボットの3 次元動歩行の実現を目指す ものである。但し、本論文では、床面は水平面であること を前提条件とする。 


\section{2 足動歩行システム}

本論文では、次の方法によって関節位置情報のみの記述 による 2 足動歩行制御を実現する。先ず、ロボットの腰部リ ンク中点をロボットの重心とし、倒立振子近似を行う。この 倒立振子の動作に基づいて、絶対座標系での 2 足ロボット の動作の記述を得る。ロボットの支持脚は、前後方向、左 右方向共に倒立振子のように振る舞う。得られた絶対座標 系での 2 足ロボットの動作を逆キネマティクスによって、関 節空間における動作の記述に変換し、各関節角度指令を得 る。そして、この角度指令に対する 2 自由度位置制御系を 構成し、ロバスト位置制御による歩行制御を実現する。各 関節にロバスト位置制御系を配置することにより、床面か らの反力などの外乱を瞬時に打ち消して、倒立振子動作に 基づいた動歩行を実現させる。

与える歩行軌道の妥当性については、ゼロモーメント点 (Zero Moment Point：以降 ZMP と記す)分布をあらかじめ計 算し、歩行の可能性を判別しておく。

\section{$<2.1>2$ 足動歩行ロボットの構成}

上記の目的を達成するために、図 1 に示すロボットを製作 する。図 2 にそのロボットのモデル図を示す。人間の脚の自 由度は、足首が 3 、膝が 1 、股関節が 3 の計 7 自由度に集約さ れる(12)。本論文では、足首が 2 、膝が 1 、股関節が 2 の計 5 自 由度の脚を持つ 2 足歩行ロボットを製作した。これは、ピ ポット動作のような回転して方向を変える自由度だけを無 くしたことに相当する。したがって、このロボットは、11リ ンク 10 関節を有している。矢状面 (Sagittal Plane) 内の動作 に加え、ロボットの重心を左右方向に移動するための、前 頭面(Lateral Plane) 内の動作を持たせている。

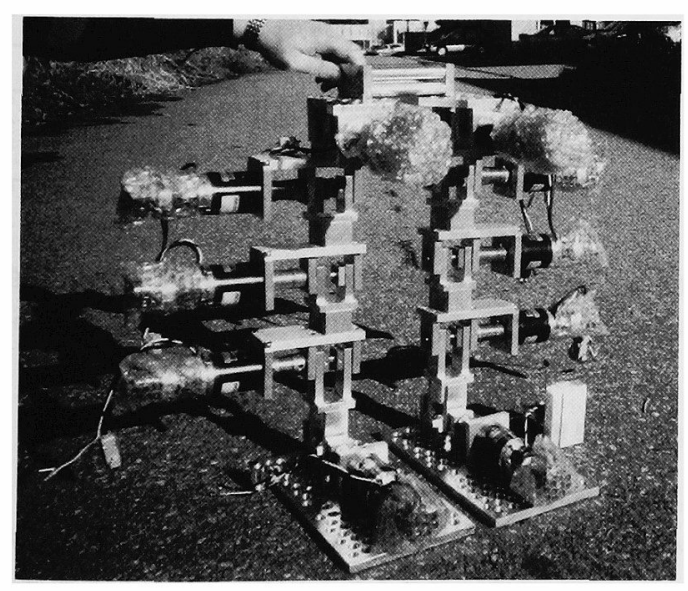

図12 足動歩行ロボット

Fig.1. Biped robot

ロール軸 ( $x$ 軸) まわりに各脚 2 自由度の計 4 自由度、ピッ チ軸 $(y$ 軸) まわりに各脚 3 自由度の計 6 自由度、合計 10 自由 度を配している。正面(Lateral Plane)内の動作を持たせるこ とにより横方向への重心の移動を可能とし、左右の足底範 囲が干涉し合わない場合でも、単脚支持を可能としている。

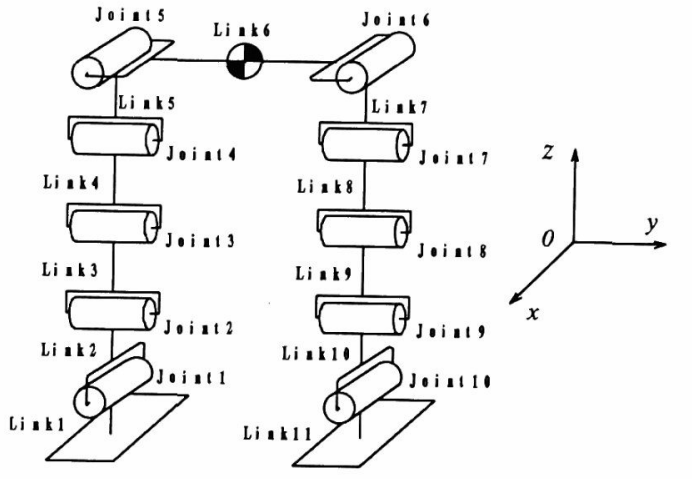

図2ロボットのモデル図

Fig.2. Model of biped robot

各関節は1:100の减速機を有するDCサーボモータによって 駆動される。各サーボモータは $1000[\mathrm{p} / \mathrm{rev}]$ の分解能のロー タリーエンコーダが直結されており、関節角度 $\theta$ をカウン タにより取得する。また、キャリア周波数 $17 \mathrm{kHz}$ の DCチョッ パへ電圧指令 $V^{\mathrm{cmd}}$ を与えることにより駆動される。表 1 に ロボットの仕様を示す。全高は $52[\mathrm{~cm}] 、$ 全幅は約 $66[\mathrm{~cm}] 、$ 総重 量は約 $18[\mathrm{~kg}]$ である。

表1 ロボットの仕様

Table 1. Specification of biped robot

\begin{tabular}{c|c|c}
\hline リンク & リンク長さ $l_{i}[\mathrm{~m}]$ & リンク 重量 $m_{\boldsymbol{i}}[\mathrm{kg}]$ \\
\hline \hline 1,11 & 0.040 & 1.948 \\
\hline 2,10 & 0.110 & 0.434 \\
\hline 3,9 & 0.110 & 1.684 \\
\hline 4,8 & 0.110 & 1.684 \\
\hline 5,7 & 0.070 & 1.540 \\
\hline 6 & 0.175 & 3.518 \\
\hline
\end{tabular}

\section{<2.2> ハードウェア構成}

図 3 にハードウェアの構成図を示す。各関節のサーボ系、 キネマティクス、そして歩行軌道生成のすべてのアルゴリ ズムは、サンプリング時間 $840[\mu \mathrm{sec}]$ のDSP(TMS320C30)の ソフトウエアによって実現される。

\section{3. ロパスト位置制御系}

各軸のモータのサーボ系は、図4に示す 2 自由度位置制 御系で実現する。本論文では、この制御系は、各関節軸に 対して全く同じ仕様で構成している。

2 自由度制御系は、目標值応答特性とロバスト性を独立 に設計できる利点を有している。また、パラメータ変動に 対しロバストな制御系を構成することで、歩行ロボット等 の多関節を有するロボット関節の制御に適したコントロー ラを構成できる。

図4の内部構造は、著者らが提案している既約分解表現 と外乱オブザーバによる 2 自由度制御系であり、ロバスト 


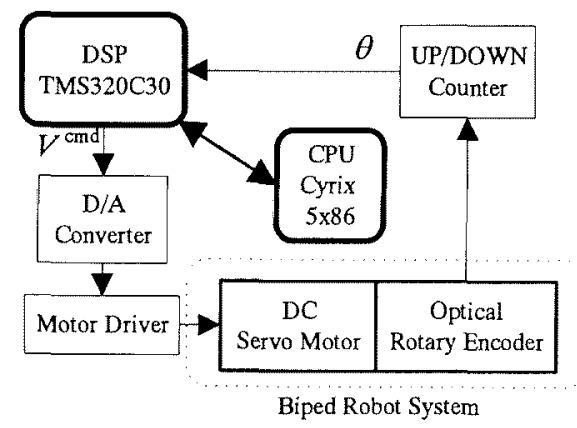

図3 制卸システム

Fig.3. Control system of biped robot

安定性を考䓛して制御系を設部することができる の内部ループ $G_{i n}$ は、状態フィードバック+状愁オブザーバ による補償器であり、制御系の安定化と特性改善を行う。ま た、外部の外乱オブザーバループは制御系のロバスト安定 化のための補償器となっている。
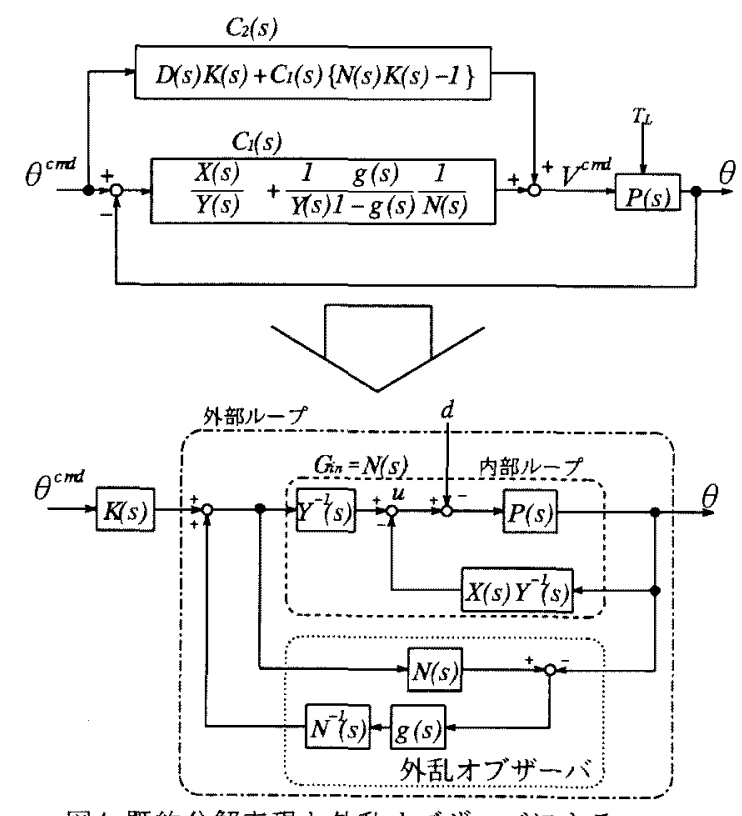

図4 既約分解表現と外乱オブザーバによる 2 自由度制御系

Fig.4. Two-degrees-of-freedom control system based on coprime factorization and disturbance observer

図4の制御系において $\theta^{\mathrm{cmd} d}$ が関節角度指令を、 $T_{L}$ が外 乱トルクをそれぞれ表している。また、 $N(s), D(s), Y(s), X(s)$ は、各関節のサーボ系の既約分解パラメータである。これ らの既約分解パラメータは、(1)式の制御对象に対する状 態フィードバックゲイン及び状態オブザーバゲインを計算 することにより求まる。また、外乱オブザーバのフィルタ $g(s)$ は、(2)式により設計する。フリーパラメータ $K(s)$ は、 目標值応答特性 $G_{r y}(s)$ を決める。

$$
\begin{aligned}
& P(s)=\frac{\theta(s)}{V^{c m d}(s)}=\frac{K_{T}}{J R s^{2}+K_{T} K_{E} s} \\
& g(s)=\frac{g_{0}}{s^{2}+g_{1} s+g_{0}} \ldots \ldots \ldots \ldots
\end{aligned}
$$

(1)式において、Jはモータイナーシャ、 $R$ は電機子抵抗、 $K_{T}$ はトルク定数、 $K_{E}$ は逆起電力定数である。本制御系の 外乱抑圧特性 $G_{d y}(s)$ 及び制御対象のパラメータ変動 $E(s)$ に 対するロバスト安定条件は、それぞれ(3),(4),(5)式となる。

$$
\begin{aligned}
& G_{d y}(s)=Y(s) D(s)(1-g(s)) \\
& G_{i n}(s)=\hat{G}_{i n}(s)\left\{1+E_{i n}(s)\right\} \\
& =\hat{G}_{i n}(s)\left\{1+\frac{Y(s) D(s) E(s)}{1+N(s) X(s) E(s)}\right\} \\
& \left\|r_{\text {in }}(s) g(s)\right\|_{\infty}<1 \quad, \quad\left|r_{\text {in }}(j \omega)\right| \geq\left|E_{\text {in }}(j \omega)\right|^{\forall} \omega
\end{aligned}
$$

これらの式を用いて提案する制御系のロバスト性に関寸 る $g(s)$ の設計を行う。 $E_{i n}(s)$ は、内部ループ $G_{i n}(s)$ の乗法 的変動を表し、 $r_{i n}(s)$ は口バスト安定条件のための重み関数 となっている。具体的には、(5)式の条件式を满たし、(3)式 の感度関数の大きさをできるだけ小さく押さえ、且つ定常 状態で零にするようにボード線図上の整形により決める。 以上により、図4 の補償器 $C_{1}(s)$ と $C_{2}(s)$ が得られる。

図1の 2 足動步行ロボットが 1 秒間に最大 $10 \mathrm{~cm}$ の歩幅で 進むことを想定すると、各関節の目標值応答特性は、30 $[\mathrm{rad} / \mathrm{sec}]$ 程度必要となる。そして、その動歩行における各 関節の負担を慣性モーメントの変動と見なすと、最大值で ノミナル值の 10 倍以下となった。以上より、本サーボ系の設 計仕様は表 2 とする。

\section{表2 制御系設計仕椂}

Table 2. Specification of control system

\begin{tabular}{c|l}
\hline 目標値応答特性 $G_{r y}(s)$ & $30[\mathrm{rad} / \mathrm{sec}]$ \\
\hline 外乱抑王特性 $G_{d y}(s)$ & $50[\mathrm{rad} / \mathrm{sec}]$ \\
\hline ロバスト安定性 & モータ軸換算の慣性がノミナル值 \\
& $J_{n o m}$ の10倍変動まで安定 \\
\hline
\end{tabular}

表 2 に基づいて設計した 2 自由度制御系の周波数特性を 図5に示す。

\section{2 足動歩行制御法}

\section{<4.1> 動歩行のための動作記述}

本論文では、ロボットの步行軌道を支持脚及び遊脚先端 の 3 次元絶対座標にて与える。このとき支持脚先端は、第 6リンクの中央とし、遊脚先端を遊脚つま先（第1リンクま たは、第11リンク先端）とする。

歩行軌道生成のためにロボットの支持脚を一質点で表見 し倒立振子近似を行5。図6 は側面(Sagittal Plane)における、 倒立振子近似されたロボットを示す。このとき、重心を $G$ で示す。ここでは、第1リンク中点をこの重心にあてる。「 は振子の脚の長さである。 


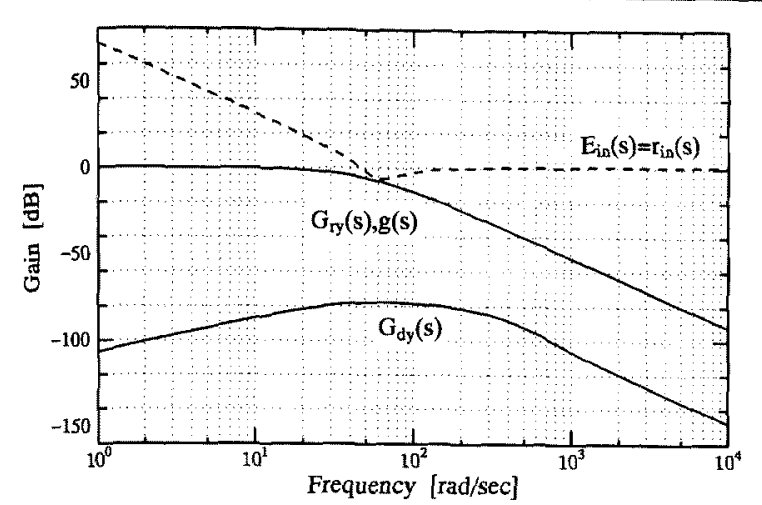

图5 ボード線図

Fig.5. Frequency characteristics of control system

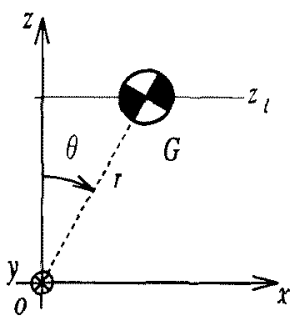

(a) Sagittal Plane

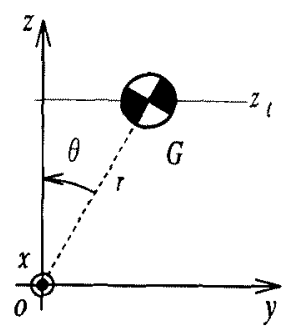

(b) Lateral Plane
図6 倒立振子近似

Fig.6. Approximation to inverted pendulum

ロボットの動作は 3 次元であるが、簡単のため統一的に は扱わず、 $x-z$ 平面で構成される Sagittal Plane拉よび $y-z$ 平面で構成されるLateral Planeに、それぞれ分けて考えるこ ととする。自然な步行では、体を左右に摇らす角度が少な いので Sagittal Plane 内の運動が、 Lateral Plane 内の運動へ 影響することがないと見なせる の運動による Sagittal Plane 内の運動への力の影響は、本論 文では、外力と見なしている。この外力の抑圧には、2自 由度制御系の $G_{d y}(s)$ の応答で十分となる様にする。Sagittal Plane の重心 $G$ について、(6)式の運動方程式を得る。

$$
M \ddot{P}=\left(J^{T}\right)^{-1} \tau+M g
$$

$$
\text { ここで、 }
$$

$$
\begin{gathered}
M=\left[\begin{array}{ccc}
m & 0 & 0 \\
0 & m & 0 \\
0 & 0 & I
\end{array}\right] \quad P=\left[\begin{array}{c}
x \\
z \\
0
\end{array}\right] \quad g=\left[\begin{array}{c}
0 \\
-g \\
0
\end{array}\right] \\
J=\frac{d P}{d \theta}=\left[\begin{array}{lll}
\frac{d x}{d \theta} & \frac{d z}{d \theta} & \frac{d \theta}{d \theta}
\end{array}\right]^{T} \ldots \ldots \ldots \ldots
\end{gathered}
$$

である。ただし、

$$
\begin{aligned}
& m \text { ：重心の質量 } I ： \text { 慣性モーメント } \\
& g \text { : 重力加速度 } \tau \text { ：原点まわりの回転トルク }
\end{aligned}
$$

である。

(6)式において、両辺に左側からヤコビ行列の転置行列 $J^{T}$ をかけて、展開すると(8)式が得られる。

$$
m \frac{d x}{d \theta} \ddot{x}+m \frac{d y}{d \theta} \ddot{z}+I \ddot{\theta}=\tau-m \frac{d z}{d \theta} g
$$

ここで図6の関倸より、(9)式を得る。

$$
\begin{aligned}
& x=r \sin \theta \quad z=r \cos \theta \\
& \frac{d x}{d \theta}=r \cos \theta=z \quad \frac{d z}{d \theta}=-r \sin \theta=-x \\
& m(z \ddot{x}-x \ddot{z})+I \ddot{\theta}=\tau+m g x
\end{aligned}
$$

Lateral Planeに扔いても同样に求められ、(9)式に対し、 (10)式老得る。

$$
-m(z \ddot{y}-y \ddot{z})+I \ddot{\theta}=\tau-m g y
$$

(9),(10)式について、重心の高さが一定である肳束条件の $z=z_{l}$ (const.)、重心が等速運動する拘束条件の $\ddot{\theta}=0^{(10)}$ 、自 由振り子運動のための必要十分条件の $r=0$ を代入寸ると、 それぞれは(11),(12)式となる。

$$
\ddot{x}-\frac{g}{z_{l}} x=0
$$

$$
\ddot{y}-\frac{g}{z_{l}} y=0
$$

ここで、 $z_{i}$ は、支持脚先端の高さを表す。

(11)および(12)式の微分方程式を解けば、これらは絶対 座標系での振子の動作、すなわち、支持脚先端の軌道指令 となる。それぞれを解くと、(13)および(14)式となる。

$$
\begin{aligned}
& x(t)=\frac{v_{x 0}}{\alpha} \sinh (\alpha t) \\
& y(t)=\frac{v_{y 0}}{\alpha} \sinh (\alpha t)
\end{aligned}
$$

ただし、

$$
\alpha=\sqrt{\frac{g}{z_{l}}} \quad \begin{array}{ll}
x(0)=0 & \dot{x}(0)=v_{x 0} \\
y(0)=0 & y(0)=v_{y 0}
\end{array}
$$

である。

遊脚の軌道については、本論文では、歩行に支障をきた さないように定めている。この軌道の妥当性は、後述の妥 当性の検討で判断される。

\section{$\langle 4.2\rangle$ 関節角度の生成について}

歩行のための 3 次元軌道から、各関節角度指令を生成す る。このために、関節座標系と直交座標系を結びつけてい るキネマティクスを求める。この際に、支持脚及び遊脚に ついて別タにキネマティクスを計算する。支持脚は、直交座 標系原点から第6リンク中点までとし、遊脚は、第6リンク 中点から遊脚先端までとする。これにより、直交座標系と 関節座標系を結びつけている逆キネマティクスを得る(15)。 得られた逆キネマティクスは、支持脚及び遊脚の足首と胴 


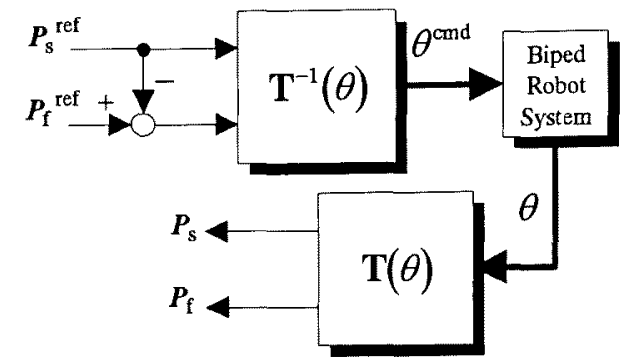

図7 步行制御系全体図

Fig.7. Total control system of biped robot

体リンクが、床面に対して常に鉛直となる関節角度指令を 生成する。

図7に、歩行制御系全体のブロック図を示守。

遊脚の軌道は、直交座標系原点を基淮とした遊脚先端の 座標となっているので、そのままでは、遊脚の逆キネマティ クスに適用できない。そこで、図7では、遊脚の軌道座標 から支持脚の軌道座標を差し引くことで、遊脚の逆キネマ ティクスへ適用している。

$\langle 4.3\rangle$ 歩行軌道の妥当性について

実際に 2 足動歩行を行う前に、(13),(14)式によって与える 歩行軌道が歩行を可能とするものであるかどうかを、あら かじめ判別しておかなければならない。本論文ではZMP 分 布を解析することによって歩行の可能性を判別する $x, y$ 各方向のZMP、 $x_{Z M P}, y_{Z M P}$ は次式で与えられる。

$$
\begin{aligned}
x_{\mathrm{ZMP}} & =\frac{\sum_{i=1}^{n} m_{i}\left(\ddot{z}_{i}+g\right) x_{i}-\sum_{i=1}^{n} m_{i} \ddot{x}_{i} z_{i}}{\sum_{i=1}^{n} m_{i}\left(\ddot{z}_{i}+g\right)} \\
y_{\mathrm{ZMP}} & =\frac{\sum_{i=1}^{n} m_{i}\left(\ddot{z}_{i}+g\right) y_{i}-\sum_{i=1}^{n} m_{i} \ddot{y}_{i} z_{i}}{\sum_{i=1}^{n} m_{i}\left(\ddot{z}_{i}+g\right)} .
\end{aligned}
$$

ただし、

$$
\begin{aligned}
\left(x_{i}, y_{i}, z_{i}\right) & : i \text { 番目のリンクの重心位䍛 } \\
m_{i} & : i \text { 番目のリンクの質量 } \\
g & : \text { 重力加速度 }
\end{aligned}
$$

実際の步行軌道解析は、次の条件によって行った。

$$
\begin{aligned}
& \text { ・ } 1 \text { 歩に要する時間 } 1[\mathrm{sec}] \\
& \text { ・ } 1 \text { 歩の距離 腰部 } 4[\mathrm{~cm}]
\end{aligned}
$$$$
\text { 遊脚先端 } 4[\mathrm{~cm}] \text { (1 步目) }
$$$$
8[\mathrm{~cm}] \quad \text { ( } 2 \text { 歩目以降) }
$$

図8 は、与える歩行軌道の歩行中の ZMP 分布をシミュ レーションによって解析した結果を示したものであり、破線 で囲まれた範囲が支持脚足底範囲である。步行中は支持脚 足底内にZMPが分布しており、この歩行軌道は妥当である と言える。

$$
<4 \cdot 4>\text { 歩行アルゴリスム }
$$

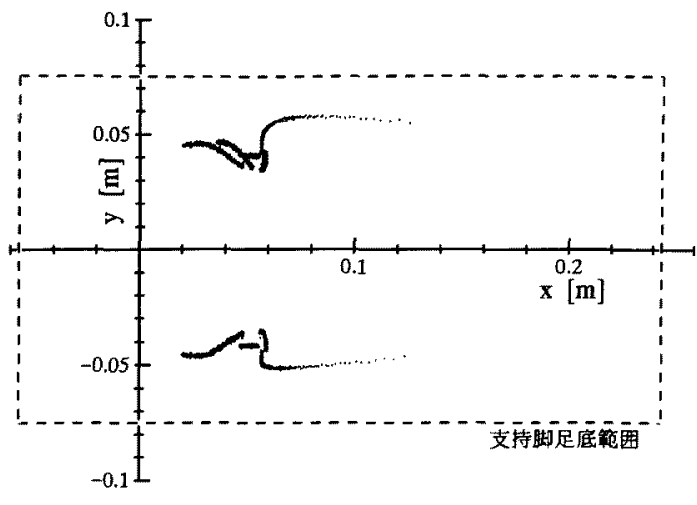

図 8 ZMP 解析

Fig.8. Analyze of ZMP

步行動作は、基準姿勢である直立姿勢から始める。その アルゴリズムを概略的に示すと、図9のようになる。

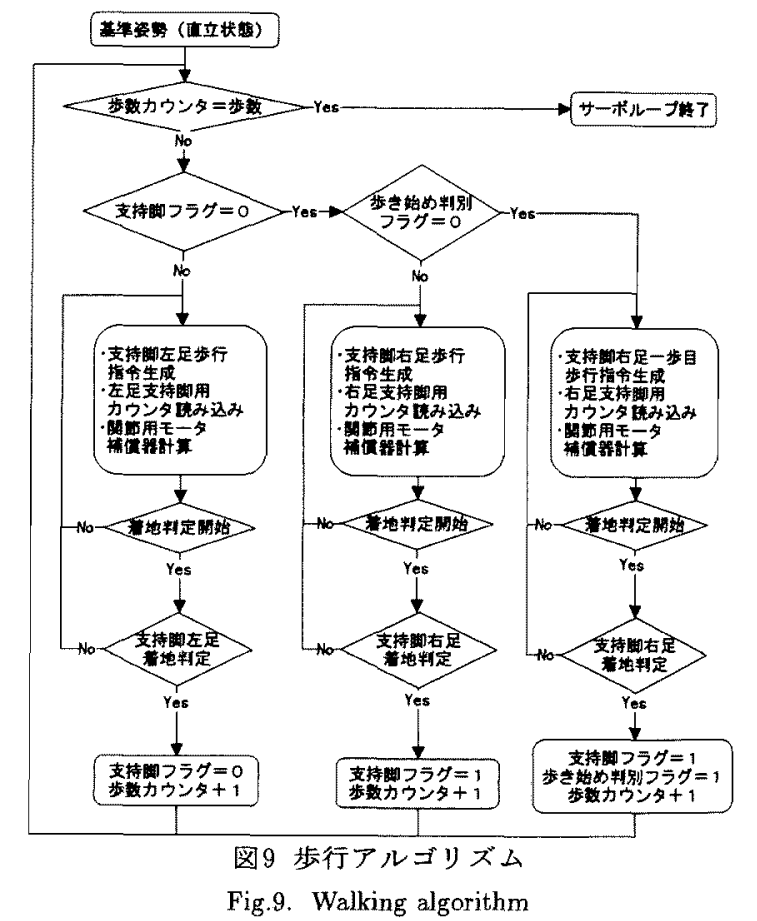

先ず、歩数カウンタと指令歩数を比較し、歩数カウンタ が指令歩数に等しくなればサーボルーブを終了する。歩数 カウンタが指令歩数よりも少ない場合、支持脚フラグによ り、左右の脚を遊脚と支持脚のどちらに使うかを決定する。 この時点で、支持脚と遊脚の入れ替えが行われる。したがっ て、脚の入れ替えは 1 歩が終了した後の定常状態において 行われることになる。さらに、右足支持の場合、歩き始め 判別フラグにより、基準状態からの步き始めかどうかを判 別する。ここで、紫行指令の生成、各関節軸の位置の読み とり、補償器計算を繰り返し行う。歩行指令が定常状態と なってから、遊脚の着地判定を行う。着地判定は、各関節の 位膡情報を順キネマティクスによって直交座標での先端位 


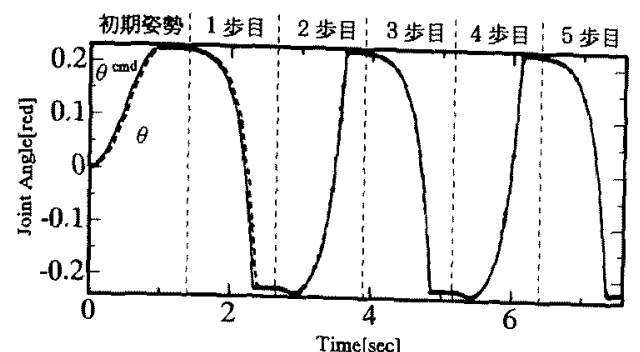

(a) Joint 1

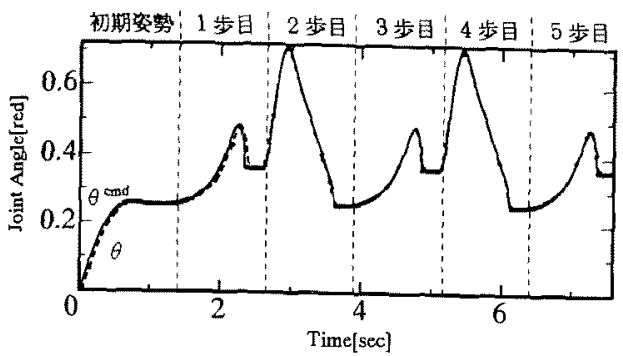

(b) Joint 2
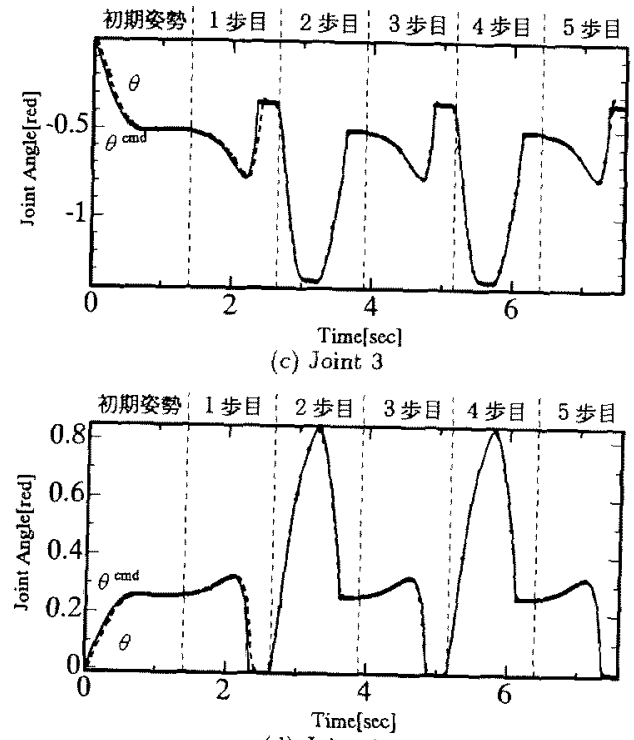

(d) Joint 4

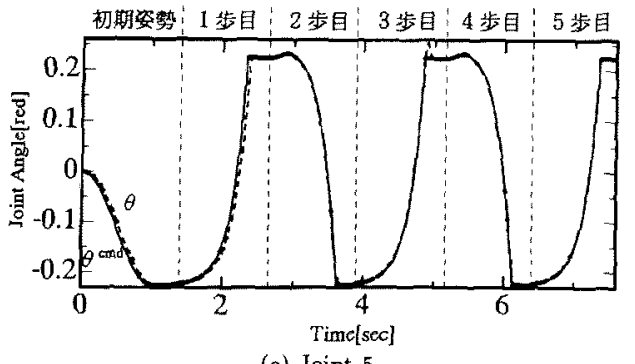

(e) Joint 5

図 10 各関節角度芯答

Fig.10. Angle responses of each joint

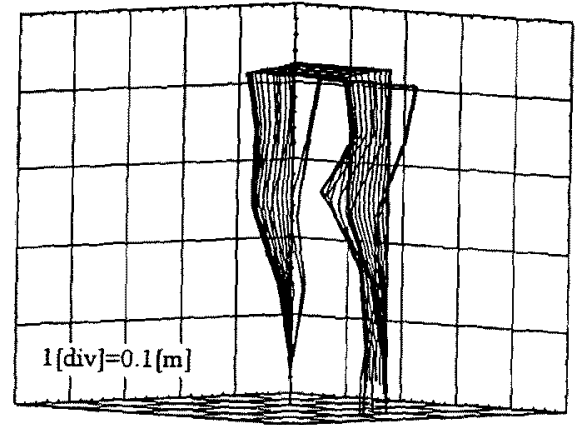

（a） 1 歩目終了まで

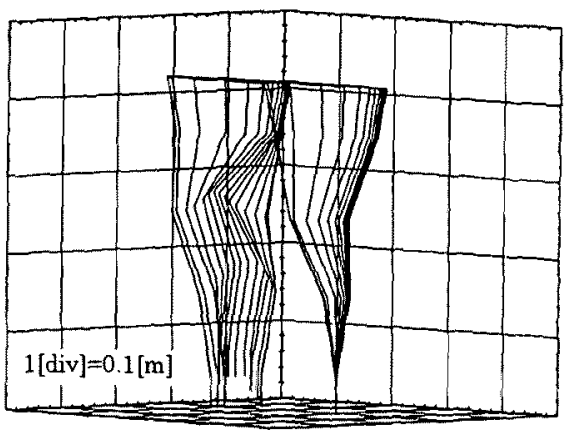

(b) 2 歩目

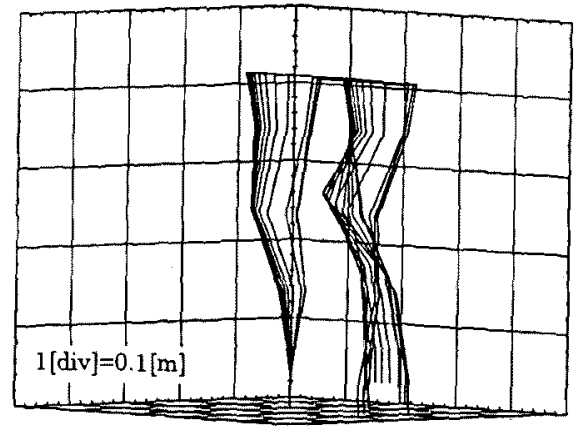

(c) 3步目

図11 スティック線図

Fig.11. Stick diagram 
置を計算して行う。着地したとされたら現在の歩の終わり となり、歩数カウンタに1を加え、支持脚フラグを入れ替え て、新たな歩を始めるために、歩数カウンタのチェックへ戻 る。以降この綝り返しで歩行が継続される。

\section{5. 実験結果}

上記の歩行軌道と歩行アルゴリズムを用いて歩行実験を 行った。その各関節角度忘答を図 10 、スティック線図を図 11 にそれぞれ示す。

図10 は、右足の各関節角度指令およぴ忍答を示してい る。右足は1歩目，3歩目，5歩目に扔いて支持脚となり、2 歩目, 4歩目では遊脚となる。角度応答は、多少のオーバー シュートが見受けられるが、いずれの場合においても指令 值によく追従できており、各関節をロバストに位置制御で きていることが確認される。

図11 は、実験により得られた角度応答をスティック線図 で表したものである。図11 (a) は、基準姿勢から1歩目終了 までを示し、(b) は2歩目を、(c)は3歩目をそれぞれ示して いる。それぞれより、2 足動歩行ができていることが確認 される。実際の歩行では、遊脚着地の瞬間にロボットの姿 勢が若千乱れているが、所望の姿勢を達成していることが 確認できた。実現した歩行は、支持脚が加速運動し、それ を着地点で支えるように遊脚を置きに行く歩行となった。 着地時に受ける床の反力の影響を、各関節軸に配したロバ スト位置制御系が外乱として瞬時に打ち消すことで、歩行 を継続している。

本論文で提案している歩行制御は、各関節のロバスト位 置制御系により、倒立振子運動を用いて記述した遊脚及び 支持脚の軌道を確実に実現するものである。したがって、本 制御系では、反力等の外乱の影響をロバスト位置制御系で 打ち消せなくなった場合が歩行継続の限界だと考えらる。 これは、一歩に要する時間を短くしたとき、あるいは歩幅 を大きくとったときなどの場合に相当する。

\section{6. まとめ}

本論文では、2 足動歩行ロボットの新しい歩行制御法を 提案した。提案する手法は、倒立振子近似モデルとキネマ ティクスにより、支持脚の歩行軌道の計算を簡単にしてい る。また、支持脚と遊脚について別々にキネマティクスを計 算することで、サーボモータへの角度指令生成を簡単にし ている。さらに、生成された角度指令は、各関節軸に施さ れた 2 自由度位置制御系によって、ロバストに制御される。 各関節軸の 2 自由度位置制御系は、2 足動歩行時の慣性変 動に対してロバスト安定となるように設計される。

提案する制御法を実際の 2 足動歩行ロボットに適用し、 実験によってその歩行が確認された。今後は、凹凸や摩擦 係数が変化する路面など、さまざまの路面に対応できる歩 行制御法一発展させてゆきたい。

(平成 9 年 2 月 25 日受付, 平成 9 年 6 月 27 日再受付)

\section{文献}

（1）高西・石田・山崎・加藤：「2 足歩行ロボットWL-10RDによる 動歩行の実現」, 日本ロボット学会誌, 3, 4, 325 336 (昭60-4)

(2) 高西:「上体の運動によりモーメントを補償する2足歩行口 ボット」, 日本ロボット学会誌, 11, 3, 348〜353 (平5-3)

（3）宮崎・有本：「特異提動法による多自由度二足歩行系の解析」， 計測自動制御学会論文集, 15, 4, 498 504（昭54-8）

（4）古荘・森塚・增淵：「局所フィードバックの概念を考慮した2足 歩行の低次元モデル」, 計測自動制御学会論文集, 17, 5, 596〜 601 (昭56-8)

（5）梶田・谷：「凹凸路面における動的 2 足歩行の制御について」, 計测自動制御学会論文集, 27, 2, 177 184（平2-2)

（6）佐野・古荘：「角運動量制御による 2 足歩行ロボットの 3 次元 動歩行」、計測自動制御学会論文集, 26, 4, 459 466 (平2-4)

（7）駒田・村上・大西:「加速度に基づく多自由度ロボットのカフィー ドバック制御」，電学論 D, 109, 5, 325〜332 (平元-5)

(8) K. Ohnishi, M. Shibata and T. Murakami, "Motion Control for Advanced Mechatronics", IEEE/ASME Trans on Mechatronics, Vol.1, No.1 pp.56-67, (1996-3)

（9）大石・大西・宮崎：「ロバスト速度コントローラに基づく多関 節ロボットのーモーション制御法」, 電学論 D, 116, 2, 144 151 (平 8-2)

(10) 空尾・村上・大西：「安定性を考慮した 2 足歩行ロボットのイ ンピーダンス制御」, 平成 8 年電気学会産業応用部門全国大 会講演論文集 $[\mathrm{III}]$, No.275

(11) 南方・堀:「Biped Bike に関する研究一矢状面運動の解析と制 御一」, $\mathrm{b}$ 平成 8 年電気学会産業态用部門全国大会講演論文集 [III], No.277

(12) M. Vukobrotvić (加藤・山下訳)：「歩行ロボットと人工の足」， 日刊工業新聞社, (昭 50)

(13) K.Ohishi, T.Miyazaki and Y.Nakamura: "High Performance Ultra-Low Speed Servo System Based on Doubly Coprime Factrization and Instantaneous Speed Observer", IEEE/ASME Trans. on Mechatronics, Vol.1, No.1 (1996-3)

(14) 下山・三浦・光石 :「 2 足歩行ロボットBIPER-4の動歩行に関 する研究」，機学論 C, 49, 444, 1372 1381 (昭 58-8)

(15) 広瀬:「ロボット工学一機械システムのベクトル解析一」, 裳 華房(昭62)

真 島勝行 (学生員) 1972年11月4日生まれ。1995年3月

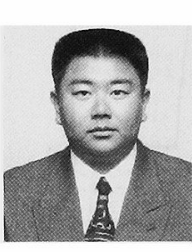
長岡技術科学大学電子機器工学課程卒業。同 年 4 月同大学大学院工学研究科入学。現在主 として、ロボティクスに関する研究に従事。

宮 崎敏 昌

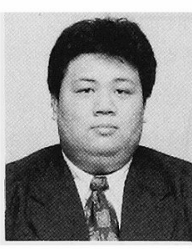

大石潔

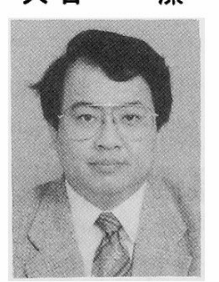

(学生員) 1971年12月8日生まれ。1994年3月 長岡技術科学大学電子機器工学課程卒業。1996 年 4 月 同大学大学院工学研究科電気・電子シス テム工学専攻修士課程修了。同年 4 月同大学 院エネルギー・環境工学専攻博士課程入学。 現在主として、電動機制御とモーションコン トロールに関する研究に従事。

(正員) 1957 年 10 月 14 日生まれ。1981年3月 慶応大学工学部電気工学科卒業。1986年3月 同大学大学院工学研究科博士課程修了。大阪 工業大学講師、助教授を経て、1993年 4 月長岡 技術科学大学電気系助教授、現在に至る。エ 学博士。主として、制御エ学、パワーエレク トロニクス、ロボティクスに関する研究に従 事。IEEE会員など。 